\title{
Seroprevalence of Neospora caninum in Sheep and Goats from Grenada, West Indies
}

\author{
Ravindra Nath Sharma*, Jehna Bush, Keshaw Tiwari, Alfred Chikweto, \\ Muhammad Iqbal Bhaiyat \\ Department of Pathobiology, School of Veterinary Medicine, St. George's University, Grenada, West Indies \\ Email: *rsharma@sgu.edu, JehnaBush/student@sgu.edu,ktiwari@sgu.edu, achikweto@sgu.edu, \\ mibhaiyat@sgu.edu
}

Received 24 September 2015; accepted 13 November 2015; published 16 November 2015

Copyright (C) 2015 by authors and Scientific Research Publishing Inc.

This work is licensed under the Creative Commons Attribution International License (CC BY). http://creativecommons.org/licenses/by/4.0/

(c) (i) Open Access

\begin{abstract}
Neospora caninum ( $N$. caninum), an intracellular protozoan parasite, causes abortion and neonatal mortality in many herbivores including sheep and goats. The aim of this study was to estimate the Seroprevalence of $N$. caninum in sheep and goats in Grenada, West Indies. Sera were collected from 138 sheep and 138 goats from all six parishes of Grenada and Carriacou, a small island within Grenada. Animals were identified by gender. Sera were tested for antibodies for $N$. caninum using an indirect Enzyme Linked Immunosorbant Assay (ELISA) multispecies Kit from Pourquire Laboratorie (IDvet, France). Antibodies to $N$. caninum were detected in 18 of 138 sheep (13\%, 95\% confidence interval (CI): $7.39 \%$ to $18.61 \%)$ and 8 of 138 goats (5.8\%, 95\% CI: $1.9 \%$ to $9.7 \%)$. Although seropositivity was high in female sheep and in male goats, there was no statistical difference in seropositivity of males and females in both species of animals $\left(p>0.05, \chi^{2}\right)$. The results of this study revealed that sheep and goats in Grenada were exposed to $N$. caninum and dogs might be considered as a source of infection. There was a need to educate the farmers, possessing small ruminants, about the transmission cycle of $N$. caninum and methods of prevention, to minimize the exposure of their flocks. This is the first report on seroprevalence of $N$. caninum in Grenada, West Indies.
\end{abstract}

\section{Keywords}

Grenada, Neosporacaninum, Seroprevalence, Sheep/Goats

${ }^{*}$ Corresponding author.

How to cite this paper: Sharma, R.N., Bush, J., Tiwari, K., Chikweto, A. and Bhaiyat, M.I. (2015) Seroprevalence of Neospora caninum in Sheep and Goats from Grenada, West Indies. Open Journal of Veterinary Medicine, 5, 219-223. 


\section{Introduction}

Neospora caninum is an intracellular protozoan parasite. Dogs and coyotes are definitive hosts which shed infective oocyst in feces. Infected dogs suffer from neuromuscular disorders [1]. Intermediate hosts, mainly herbivores (cattle, sheep, goat, horse, bison and deer), get infected by ingestion of oocysts. The parasite can be transmitted transplacentally in several hosts including cattle, in which it is a major route of transmission. The parasite causes economic losses in intermediate hosts through abortion and neonatal mortality. It is a major cause of abortion in cattle, in many countries. Pregnant sheep are highly susceptible to experimental infection by N. caninum [2].

Seroprevalence of $N$. caninum in sheep and goats has been reported from a few countries of the world. In sheep it has been reported from Slovakia, [3], Brazil [4] [5], and New South Wales [6]. In goats it has been reported from Poland [7], Brazil [8] and Romania in dairy goats [9]. As far as the authors are aware, there is no published research on $N$. caninum in sheep and goats from the Caribbean region including Grenada.

The aim of this study is to report for the first time the seroprevalence of $N$. caninum in sheep and goats from Grenada, West Indies.

\section{Material and Methods}

\subsection{Ethical Approval}

The research was approved by Institutional Animal Care and Use Committee (IACUC) of the St. George's University.

\subsection{Collection of Samples}

Grenada is the southern most of the Windward Islands of Eastern Caribbean. Its area is approximately $344 \mathrm{Km}^{2}$. It is divided in 6 parishes. Blood was collected from sheep and goats from all 6 parishes of Grenada and Carriacou. Carriacou is largest island of Grenadines, approximately $34 \mathrm{Km}^{2}$ with dependency on Grenada. To cover the representative samples, blood was collected from sheep and goats from all six parishes of Grenada and Carriacou. Blood was centrifuged at $3000 \mathrm{~g}$ for 5 minutes at $25^{\circ} \mathrm{C}$ and sera were stored at $-20^{\circ} \mathrm{C}$ until tested.

A total of 138 blood samples from goats, and same number of samples from sheep, were collected for assay. It included 35 blood samples from goats and 35 from sheep, from Carriacou. Both species of animals were identified by gender.

\subsection{Methodology}

A commercial ELISA N. caninum multispecies kit from Pourquier Laboratories (IDvet, France) was used, for detection of $N$. caninum antibodies, according to manufacturer's instructions. According to manufacturer N. caninum multispecies kit has $100 \%$ sensitivity and $100 \%$ specificity.

\subsection{Statistical Analysis}

A Chi-square test $\left(\chi^{2}\right)$ of significance for comparison of seroprevalence of $N$. caninum in sheep and goats was used (http://www.graphpad.com/quickcalcs/contingency).

\section{Results}

As shown in Table 1, antibodies to $N$. caninum were detected in 18 of 138 sheep (13\%, 95\% confidence interval (CI): $7.39 \%$ to $18.61 \%$ ) and 8 of 138 goats (5.8\%, 95\% CI: $1.9 \%$ to $9.7 \%)$. Chi-square value for comparison of seroprevalence in sheep and goats is as follows: Chi-squared equals 3.439 with 1 degree of freedom. The two tailed $P$ value corresponding to chi-squared value is equal to 0.0637 .

Table 2 shows gender wise positivity in both species of animals. Out of 18 sheep that were positive, 2 were male (5.88\%) and $16(15.3 \%)$ females. In goats, 5 males of $45(11.1 \%)$ tested were positive, while only 3 females of 93 tested were positive (3.2\%).

Seroprevalence of $N$. caninum according to parish is shown in Table 3. 
Table 1. Seroprevalence of Neospora caninum in sheep and goats from Grenada (West Indies).

\begin{tabular}{cccc}
\hline Species of animal & Number of tested & Number of positive & Percent positive \\
\hline Sheep & 138 & 18 & $13.0 \%$ \\
Goats & 138 & 8 & $5.8 \%$ \\
\hline
\end{tabular}

Table 2. Seroprevalence of Neospora caninum in sheep and goats from Grenada (West Indies) according to gender.

\begin{tabular}{rcccccc}
\hline \multirow{2}{*}{ Sex } & \multicolumn{3}{c}{ Sheep } & \multicolumn{3}{c}{ Goats } \\
\cline { 2 - 7 } & No. tested & No. positive & Percent positive & No. tested & No. positive & Percent positive \\
\hline Male & 34 & 2 & 5.88 & 45 & 5 & 11.1 \\
Female & 104 & 16 & 15.3 & 93 & 3 & 3.2 \\
\hline
\end{tabular}

Table 3. Proportion of sheep and goats seropositive to Neospora caninum according to parish in Grenada, WI.

\begin{tabular}{ccccc}
\hline Parish & $\begin{array}{c}\text { Sheep } \\
\text { No. positive/No. tested }\end{array}$ & $\begin{array}{c}\text { Goats } \\
\text { No. positive/No. tested }\end{array}$ & $\begin{array}{c}\text { Sheep } \\
\text { Percentage positive }\end{array}$ & $\begin{array}{c}\text { Goats } \\
\text { Percentage positive }\end{array}$ \\
\hline St. George & $1 / 11$ & $0 / 24$ & $9 \%$ & $0 \%$ \\
St. David & $4 / 20$ & $1 / 18$ & $20 \%$ & $5.5 \%$ \\
St. Andrew & $5 / 37$ & $0 / 27$ & $13.5 \%$ & $0 \%$ \\
St. Patrick & $0 / 5$ & $2 / 15$ & $0 \%$ & $0 \%$ \\
St. Mark & $0 / 15$ & $0 / 10$ & $0 \%$ & $0 \%$ \\
St. John & $4 / 15$ & $0 / 9$ & $26.7 \%$ & $13 \%$ \\
Carriacou & $4 / 35$ & $5 / 35$ & $11.8 \%$ & $14.2 \%$ \\
\hline
\end{tabular}

\section{Discussion}

In the present study, the prevalence of antibodies for $N$. caninum in sheep is $13 \%, 95 \%$ confidence interval (CI): $7.39 \%$ to $18.61 \%$ ), which is comparable to multiple Brazilian ovine $N$. caninum seroprevalence studies: $12.8 \%$ [10] and 9.2\% [4] 10.3\% in Switzerland [11] 16.8\% from Greece [12] and 12.0\% in Czech Republic [13]. Our results were much higher compared to $N$. caninum prevalence reported from the United Kingdom 2.2\% [6], 3.7\% from Slovakia [3], 1.8\% from Brazil [5] and 2.0\% from Italy [14].

We found seroprevalence of $N$. caninum in goats at 5.8\%, which was similar with Anastasia et al. [12] who recorded $6.9 \%$ prevalence in goats in Jordan. High seropositivity compared to our results had been reported in Brazil at 15\% [8] and in Poland at 9\% [7]. In other studies, researchers found lower seroprevalence of N. caninum in goats compared to our results. Anameria et al. [9] in Romania found 2.3\% seropositivity, Eduardo et al. [15] reported 3.3\% goats with antibodies in Northeast region of Brazil; Abo-shehada and Abu-Halaweh [16] reported $2.0 \%$ seropositivity in goats, in Northern Jordon.

We reported higher prevalence of $N$. caninum antibodies in sheep (13\%) compared to goats (5.8\%) in Grenada. However, the difference was not statistically significant $\left(p>0.05, \chi^{2}\right)$. Anastasia et al. [12] also reported similar results while comparing the seroprevalence of $N$. caninum in these two species of animals.

In our study, there was no significant difference between the gender of sheep and goats for $N$. caninum antibody (Table 2). In sheep $15.3 \%$ females and $5.88 \%$ males had antibodies for $N$. caninum (Chi-square $=0.153$, $p$-value 0.70 ), while in goats $11.1 \%$ males and $3.2 \%$ females had antibodies for $N$. caninum (Chi-Square $=0.004$, $p$-value $=0.95$ ). Eduardo et al. [15] also found no association between sex of goats and prevalence of anti- $N$. caninum antibodies. Similar studies comparing seroprevalence of $N$. caninum with gender was not available for sheep.

A few studies indicated the correlation between the presence of dogs on the farm and seroprevalence for $N$. caninum in small ruminants [16]. Herbert et al. [5] and Gustavo et al. [17] suggested positive correlation be- 
tween the presence of dogs on the farm and seroprevalence of antibodies to $N$. caninum in sheep and goats. However, Figliuolo et al. [4] reported no association between dogs and prevalence of $N$. caninum antibodies in sheep.

There was paucity of information on neosporosis in dogs in the Caribbean region. A study conducted 6 years ago, on a small number of dogs, in Grenada revealed 1.8\% seropositivity using indirect immunofluorescent antibody test (IFAT) [18]. Recent study by Sharma et al. [19] using ELISA revealed low seroprevalence (1.4\%) of $N$. caninum in Grenadian dogs. Since dogs were positive for $N$. caninum antibodies and the results of this study revealed antibodies to $N$. caninum in of sheep and goats, therefore in Grenada, dogs might be considered as a source of infection to small ruminants. Further studies were warranted to assess this hypothesis.

$N$. caninum was considered as a major pathogen for cattle and dogs. It occasionally caused clinical infections in horses, sheep, goats and deer [1]. There was a poor documentation of reproductive disorders in Grenada, by farmers, in their sheep and goats. There was an urgent need for campaign to educate farmers about keeping a good record of reproductive disorders in their sheep and goat flocks in order to assess the role of $N$. caninum in clinical cases of reproductive disorders. Farmers might further be made aware to maintain hygienic conditions without presence of dogs on the small ruminant flocks.

\section{Acknowledgements}

This research was supported by Small Research Grant Initiative (SRGI) fund from the St. George's University, Grenada.

\section{Competing Interests}

The authors declare that there is no competing interest.

\section{References}

[1] Dubey, J.P. (2003) Review of Neospora caninum and Neosporosis in Animals. The Korean Journal of Parasitology, 41, 1016. http://dx.doi.org/10.3347/kjp.2003.41.1.1

[2] Innes, E.A., Lunden, A., Estaban I., Marks, J., Maley, S., Wright, S., Rao, A., Hakins, D., Vermuelen, A., McKendrick, I.J. and Buxton, D. (2001) A Previous Infection with T. gondii Does Not Protect against a Challenge with N. caninum in Pregnant Sheep. Parasite Immunology, 23, 121-132. http://dx.doi.org/10.1046/j.1365-3024.2001.00361.X

[3] Spilavska, S., Reiterova, K., Kovacova, D., Bobakova, M. and Dubinsky, P. (2009) The First Finding of Neospora caninum and T. gondii and the Occurrence of Other Abortificient Agents in Sheep in Slovakia. Veterinary Parasitology, 164, 320-323. http://dx.doi.org/10.1016/j.vetpar.2009.05.020

[4] Figliuolo, L.P.C., Kasai, N., Ragozo, A.M.A., de Paula, V.S.O., Dias, R.A., Souza, S.L.P. and Gennari, S.M. (2004) Prevalence of Anti-Toxoplasma gondii and Anti-Neospora caninum Antibodies in Ovine from Sao Paulo State, Brazil. Veterinary Parasitology, 123, 161-166. http://dx.doi.org/10.1016/j.vetpar.2004.06.006

[5] Herbert, S.S., Silvia, M.M.A., Ana, C.D.S.B., Hilda, F.J.P., Ricardo, A.D. and Solange M.G. (2009) Prevalence of Anti-Toxoplasma gondii and anti-Neospora caninum Antibodies in Sheep from Mossorro, Rio Grande do Norte, Brazil. Veterinary Parasitology, 160, 211-214. http://dx.doi.org/10.1016/j.vetpar.2008.10.102

[6] Bishop, S., King, J., Windsor, P., Reichel, M.P., Ellis, J. and Slapita, J. (2010) The First Report of Ovine Cerebral Neosporosis and Evaluation of Neospora caninum Prevalence in Sheep in New South Wales. Veterinary Parasitology, 170, 137-142. http://dx.doi.org/10.1016/j.vetpar.2010.01.030

[7] Michal, C., Jaroslaw, K., Olga, S.J., Mariusz, N., Lucjan, W. and Tadeusz, F. (2011) Seroprevalence of Toxoplasma gondii and Neospora caninum Infections in Goats in Poland. Veterinary Parasitology, 178, 339-341. http://dx.doi.org/10.1016/j.vetpar.2011.01.039

[8] Uzeda, R.S., Pinheiro, A.M., Fernandez, S.Y., Ayres, M.C.C., Godim, L.F.P. and Almeida, M.A.O. (2007) Seroprevalence of Neospora caninumin Dairy Goats from Brazil. Small Ruminant Research, 70, 257-259. http://dx.doi.org/10.1016/j.smallrumres.2006.04.003

[9] Anamaria, I., Adriana, G., Viorica, M., Raluca, G. and Vasile, C. (2012) Seroprevalence of Toxoplasma gondii and Neospora caninum in Dairy Goats from Romania. Veterinary Parasitology, 186, 470-474. http://dx.doi.org/10.1016/j.vetpar.2011.11.062

[10] Langoni, H., Junior, H.G., Guimaraes, F.F., Ulman, L.S., Gairo, F.C., Uehara, R.S., Rosa, E.P., Amorim, R.G., Silva, R.C. (2010) Serological Profile of Toxoplasma gondii and Neosporosis caninum Infection in Commercial Sheep from 
Sao Paulo State, Brazil. Veterinary Parasitology, 177, 50-54. http://dx.doi.org/10.1016/j.vetpar.2010.11.024

[11] Hassig, M., Sager, H., Reitt, K., Ziegler, D., Strabel, D. and Gottstein, B. (2003) Neospora caninum in Sheep: A Herd Case Report. Veterinary Parasitology, 117, 213-220. http://dx.doi.org/10.1016/j.vetpar.2003.07.029

[12] Anastasia, D., Elias, P., Nikolaos, P., Charilaos, K. andektarios, G. (2013) Toxoplasma gondii and Neospora caninum Seroprevalence in Dairy Sheep and Goats Mixed Stock Farming. Veterinary Parasitology, 198, 387-390. http://dx.doi.org/10.1016/j.vetpar.2013.09.017

[13] Bartova, E., Sedlak, K. and Literak, I. (2009) Toxoplasma gondii and Neospora caninum Antibodies in Sheep in the Czech Republic. Veterinary Parasitology, 161, 131-132. http://dx.doi.org/10.1016/j.vetpar.2008.12.022

[14] Gaffari, A., Giacometti, M., Tranquillo, V.M., Magnito, S., Cordiolo, P. and Lanfranchi, P. (2006) Serosurvey of Roe Deer, Chamois and Domestic Sheep in Central Italian Alps. Journal of Wildlife Diseases, 42, 685-690. http://dx.doi.org/10.7589/0090-3558-42.3.685

[15] Faria, E.B., Gennan, S.M., Pena, H.F.J., Cella, A., Maria, R.A., Silva, L.C.R. and Azevedo, S.S. (2007) Prevalence of anti Toxoplasma gondii and Neospora caninum Antibodies in Goats Slaughtered in the Public Slaughterhouses of Patos City, Paraiba State, Northwestern Region of Brazil. Veterinary Parasitology, 149, 126-129. http://dx.doi.org/10.1016/j.vetpar.2007.07.009

[16] Abo-Shehada, M.N. and Abu-Halaweh, M.M. (2010) Flock Level Seroprevalence of and Risk Factors for Neospora caninum among Sheep and Goats in Northern Jordan. Preventive Veterinary Medicine, 93, 25-32. http://dx.doi.org/10.1016/j.prevetmed.2009.08.004

[17] Machedo, G.P., Kikuti, M., Langoni, H. and Paes, A.C. (211) Seroprevalence and Risk Factors Associated with Neosporosis in Sheep and Dogs from Farms. Veterinary Parasitology, 182, 356-358.

[18] Dubey, J.P., Stone, D., Kwok, O.C.H. and Sharma, R.N. (2008) Toxoplasma gondii and Neospora caninum Antibodies in Dogs from Grenada, West Indies. Journal of Parasitology, 94, 750-751. http://dx.doi.org/10.1645/GE-1496.1

[19] Sharma, R., Theresa, K., Tiwari, K., Alfred Chikweto, A., Thomas, D., Marta Lanza, P. and Muhhamad, I.B. (2015) Serological Evidence of Antibodies to Neospora caninum in Stray and Owned Grenadian Dogs. Tropical Biomedicine, 32, 1-5. 